\title{
PEMODELAN YIELD CURVE UNTUK PASAR OBLIGASI DI INDONESIA
}

\author{
Paulus Nurwadono \\ Handy Yunianto
}

\section{PENDAHULUAN}

Salah satu permasalahan fundamental dalam pasar instrumen berpendapatan tetap (fixed income) di Indonesia adalah tidak adanya benchmark yang dapat menjadi acuan bagi penentuan yield suatu instrumen surat utang. Ketiadaan tingkat bunga yang dapat menjadi acuan menyebabkan proses penentuan harga instrumen surat utang terlihat kurang konsisten. Inkonsistensi penentuan harga instrumen surat utang ini dapat terjadi baik itu antar rating - rating yang lebih baik dengan maturity yang sama namun mempunyai yield yang lebih tinggi - maupun dalam rating yang sama.

Sebuah yield curve pada umumnya diturunkan dari instrumen yang bebas resiko (risk free instrument) serta mempunyai berbagai tingkat masa jatuh tempo (maturity). Peningkatan aktifitas pasar sekunder obligasi pemerintah, meskipun masih terbatas pada beberapa tipe saja, memberikan peluang untuk terbentuknya suatu yield curve di Indonesia. Pembentukan yield curve diharapkan dapat mengeliminasi inkonsistensi dalam proses penentuan harga instrumen hutang tersebut secara bertahap.

Pemodelan yield curve berkembang cukup pesat, bermula dari Stephen BradleyDwight Crane (1973) ${ }^{1}$ dan Elliot-Echols (1976) ${ }^{2}$ yang mencoba melakukan pengepasan (fitting) yield curve, yaitu mencari hubungan non-linear antara maturity dan yield serta efek dari kupon. Pada tahun 1971 McCulloch $^{3}$ memperkenalkan metode polinomial spline dan diperluas lagi menjadi eksponensial spline yang diperkenalkan oleh Vasicek-Fong pada tahun $1982^{4}$.

1) Stephen P Bradley and Dwight B Crane, "Management of Commercial Bank Government Security Portfolio: An Optimization Approach under Uncertainty", Journal of Bank Research, Spring 1973, pp. 18-30.

2) Michael E Echols and Jan Walter Elliot, "A Quantitative Yield curve Model for Estimating the Term Structure of Interest Rate", Journal of Financial and Quantitative Analysis, March 1976, pp. 87-114

3) J.H. McCulloch," Measuring Term Structure Interest Rate," Journal of Business, 44:19-31, 1971

4) O.A. Vasicek and H.G. Fong, "Term Structure Modeling using Exponential Spline," Journal of Finance, 329:348, 1982 
Model yield curve yang lain diperkenalkan oleh Nelson-Siegel (1987) ${ }^{5}$ dan Svenson $(1994)^{6}$ yang melakukan alternatif pemodelan yield curve dengan menurunkannya dari model parametrik bentuk fungsi forward rate. Model yield curve terbaru pada tahun $1999^{7}$ oleh Richard Deaves-Mahmut Parlar yaitu generalized bootstrap method merupakan gabungan antara bootstrap dan polinomial spline.

Paper ini berupaya untuk mencari model penyusunan yield curve yang paling layak diterapkan di Indonesia. Ada dua kendala besar dalam penyusunan Indonesian yield curve, yaitu:

1. Tidak adanya obligasi pemerintah dengan tingkat maturity jangka pendek.

2. Proses pemulusan (smoothing process) antar yield dari data yang telah dihitung pada berbagai maturitity.

Dengan melihat realitas yang ada di pasar sekunder obligasi pemerintah, eksplorasi terhadap model-model penyusunan yield curve menjadi kajian yang relevan sebelum menentukan model yang paling sesuai bagi kondisi di Indonesia.

\section{TINJAUAN TEORITIS}

Untuk mengatasi kedua kendala tersebut, maka dalam penyusunan yield curve ini digunakan metode Generalized Bootstrap, yang merupakan gabungan antara bootstrap dan polynomial spline (dalam hal ini menggunakan polynomial berordo tiga atau biasa disebut cubic spline), sedangkan untuk proses pemulusannya digunakan Bradley Crane model.

\section{Bootstrap Method}

Bootstrap digunakan untuk mencari solusi dari persamaan-persamaan non-linear yang berurutan dimana paling tidak ada satu persamaan yang solusinya diperoleh, kemudian melalui substitusi diperoleh solusi dari variabel persamaan-persamaan lainnya secara berurutan ${ }^{8}$.

5) C.R. Nelson and A.F. Siegal," Parsimonious Modeling of yield curve," Journal of Business, October 1987, pp. 473489

6) L.E.O Svensson," Estimating and Interpreting Forward Interest Rate: Sweden 1992-1994. Technical Report Discussion Paper Number 1051, Centre for Economic Policy Research, October 1994

7) R Deaves and M Parlar," A generalized Bootstrap Method to Determine the Yield curve," Research Supported by the Social Sciences and humanities Research Council of Canada and the Natural Sciences and Engineering Research Council of Canada, January 1999.

8) Fabozzi, F. J. \& T.D. Fabozzi. The Handbook of Fixed Income Securities Fourth edition. Burr Ridge, New York, 1989. 
Tahapan yang dilakukan adalah:

1. Cari solusi persamaan yang hanya mempunyai satu variabel tidak diketahui.

2. Hasil dari tahapan satu disubstitusikan ke persamaan lain yang mempunyai dua variabel tidak diketahui.

3. Hasil tahapan satu dan dua digunakan untuk mencari solusi bagi persamaan berikutnya yang mempunyai tiga varibale yang tidak diketahui, demikian seterusnya.

Salah satu kelemahan dari metode bootstrap adalah adanya syarat kecukupan tentang struktur data yang baku. Biasanya syarat kecukupan tersebut tidak dapat dipenuhi oleh data yang ada.

\section{Cubic spline}

Suatu fungsi $S$ dikatakan spline dengan pangkat $k$ pada selang $[a, b] j i k a{ }^{9)}$ :

1. S terdefinisi pada selang $[a, b]$

2. $S, S^{\prime}, S^{\prime \prime}, \ldots, S^{(k-1)}$ semuanya adalah fungsi yang kontinu pada selang $[a, b]$

3. Ada titik-titik $\mathrm{t}_{\mathrm{i}}$ (disebut juga knots pada spline $\mathrm{S}(\mathrm{x})$ ) sehingga :

$\mathrm{a}=\mathrm{t}_{1}<\mathrm{t}_{2}<\mathrm{t}_{3}<\ldots<\mathrm{t}_{\mathrm{n}}=\mathrm{b}$ dan $\mathrm{S}(\mathrm{x})$ adalah fungsi polinom dengan ordo $\leq k$ pada masingmasing sub interval $\left[t_{i}, t_{i+1}\right]$.

Cubic spline adalah himpunan bagian dari fungsi $\mathrm{S}(\mathrm{x})$ yang merupakan spline dengan berderajat $k=$ tiga, dan $\mathrm{S}(\mathrm{x})$ harulah mempunyai sifat-sifat:

1. $\mathrm{S}(\mathrm{x})$ adalah piecewise cubic pada selang $[\mathrm{a}, \mathrm{b}]$

2. $\mathrm{S}(\mathrm{x})$ kontinu pada selang $[\mathrm{a}, \mathrm{b}]$

3. $S^{\prime}(x)$ kontinu pada selang $[a, b]$

4. $\mathrm{S}^{\prime \prime}(\mathrm{x})$ kontinu pada selang $[\mathrm{a}, \mathrm{b}]$

Sedangkan untuk tujuan ekstrapolasi diasumsikan :

1. $S(x)$ didefinisikan sama dengan $S_{1}(x)$ jika $x<a$

2. $S(x)$ didefinisikan sama dengan $S_{n-1}(x)$ jika $x>b$

9) Atkinson, Elemenary Numerical Analysis second edition. John Willey \& Son, Singapore, 1994. 


$$
\mathrm{S}(\mathrm{x})=\left\{\begin{array}{ccc}
\mathrm{S}_{1}(\mathrm{x}) & ; & \mathrm{t}_{1} \leq \mathrm{x} \leq \mathrm{t}_{2} \\
\mathrm{~S}_{2}(\mathrm{x}) & ; & \mathrm{t}_{2} \leq \mathrm{x} \leq \mathrm{t}_{3} \\
\mathrm{~S}_{3}(\mathrm{x}) & ; & \mathrm{t}_{3} \leq \mathrm{x} \leq \mathrm{t}_{4} \\
\cdot & & \\
\cdot & & \\
\cdot & & \\
\mathrm{S}_{\mathrm{n}-1}(\mathrm{x}) & ; & \mathrm{t}_{\mathrm{n}-1} \leq \mathrm{i} \leq \mathrm{n}-1
\end{array}\right.
$$

dengan $S_{i}(x)=a_{i} x^{3}+b_{i} x^{2}+c_{i} x+d_{i} ; 1 \leq i \leq n-1$

Sehingga terdapat 4(n-1) variabel yang tidak diketahui pada (n-1) persamaan polinom pangkat tiga.

Syarat bahwa $\mathrm{S}(\mathrm{x})$ fungsi yang kontinu pada interior knots, $\mathrm{t}_{2^{\prime}}, \mathrm{t}_{3^{\prime}}, \ldots, \mathrm{t}_{\mathrm{n}-1}$, memberikan persamaan-persamaan sebagai berikut:

$\mathrm{S}_{1}\left(\mathrm{t}_{2}\right)=\mathrm{f}_{2}$

$\mathrm{S}_{2}\left(\mathrm{t}_{2}\right)=\mathrm{f}_{2}$

$\mathrm{S}_{2}\left(\mathrm{t}_{3}\right)=\mathrm{f}_{3}$

$\mathrm{S}_{3}\left(\mathrm{t}_{3}\right)=\mathrm{f}_{3}$

$S_{i-1}\left(t_{i}\right)=f_{i}$

$S_{i}\left(t_{i}\right)=f_{i}$

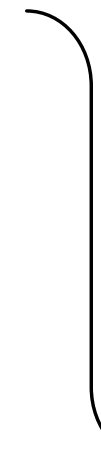

2(n-2) persamaan

$$
\begin{aligned}
& \cdot \\
& S_{n-2}\left(t_{n-1}\right)=f_{n-1} \\
& S_{n-1}\left(t_{n-1}\right)=f_{n-1}
\end{aligned}
$$

diketahui juga $S_{1}\left(t_{1}\right)=f_{1}$ dan $S_{n-1}\left(t_{n}\right)=f_{n}$. 
Syarat bahwa $\mathrm{S}^{\prime}(\mathrm{x})$ harus kontinu pada interior knots $\mathrm{t}_{2^{\prime}} \mathrm{t}_{3^{\prime}}, \ldots, \mathrm{t}_{\mathrm{n}-1}$ diperoleh (n-2) persamaan lagi. Selain itu disyaratkan pula bahwa $S^{\prime \prime}(x)$ kontinu pula pada interior knots $t_{2^{\prime}}$ $\mathrm{t}_{3}, \ldots, \mathrm{t}_{\mathrm{n}-\mathrm{1}}$ didapatkan juga sebanyak (n-2) persamaan lainnya. Sehingga diperoleh hanya (2n$4)+2+(n-2)+(n-2)=4 n-6$ persamaan untuk mencari $4 n-4$ variabel yang tidak diketahui. Oleh karenanya dibuatkan dua asumsi lagi untuk mengepaskan dengan jumlah variabel yang tidak diketahui. Biasanya asumsi yang digunakan adalah menolkan slopes dari $\mathrm{S}_{1}\left(\mathrm{t}_{1}\right)$ dan $\mathrm{S}_{\mathrm{n}-1}\left(\mathrm{t}_{\mathrm{n}}\right)$. Dengan demikian jumlah variabel yang tidak diketahui akan sama dengan jumlah persamaan, maka dengan kalkulus biasa bisa dicari solusi dari persamaan tersebut.

\section{Generalized Bootstrap Method}

Metode ini mengatasi kelemahan dari bootstrap method sebelumnya. Pada intinya metode ini adalah menduga data yield to maturity (YTM) yang tidak diketahui sehingga struktur data yang didapatkan dapat digunakan untuk penghitungan yield pada metode bootstrapping. Pendugaan data ini menggunakan metode cubic spline. Ada beberapa notasi matematis yang harus diperhatikan pada penggunaan generalized bootstrap ${ }^{10)}$.

Suatu obligasi bisa dicirikan dari maturity, kupon tahunan, frekuensi pembayaran kupon dan harga. Sehingga jika kita mempunyai sebanyak $K$ obligasi, obligasi ke-i $\left(\mathbf{B}_{\mathbf{i}}\right)$ dapat dinotasikan ke dalam vektor:

$$
\mathbf{B}_{\mathrm{i}}=\left[n_{i^{\prime}} c_{i^{\prime}} \mathbf{t}_{i^{\prime}} p_{i}\right] \quad \mathrm{i}=1,2 \ldots \mathrm{K}
$$

dengan $n_{i}$ adalah banyaknya pembayaran kupon, $c_{i}$ adalah kupon tahunan, vektor waktu $\mathbf{t}_{i}=\left[\mathbf{t}_{i 1}, \mathbf{t}_{i_{2}}, \ldots, \mathbf{t}_{i n i}\right]$ adalah daftar waktu pembayaran kupon dalam tahun dengan $\mathbf{t}_{i j}$ adalah waktu pembayaran kupon ke-j pada obligasi ke-i, dan $p_{i}$ adalah harga obligasi ke-i, sedangkan $\mathrm{t}_{i}$ ni adalah maturity dari obligasi ke- $i$

Jika diberikan data sebanyak $K$ obligasi, maka kita bisa menuliskan $K$ persamaan nonlinear sebagai berikut:

$$
P_{i}+a i_{i}=\frac{C_{i} / v}{\left(1+\frac{r_{i t_{1}}}{v}\right)^{v t_{1}}}+\frac{C_{i} / v}{\left(1+\frac{r_{i t_{2}}}{v}\right)^{v t_{2}}}+\ldots+\frac{C_{i} / v+M}{\left(1+\frac{r_{i t_{m}}}{v}\right)^{v t_{m}}}
$$

Biasanya banyaknya variabel yang tidak diketahui $\left(r_{t}\right)$ lebih banyak daripada jumlah persamaan yang tersedia, sehingga untuk menyelesaikan sistem persamaan non-linear di

10)R Deaves and M Parlar," A generalized Bootstrap Method to Determine the Yield curve," Research Supported by the Social Sciences and humanities Research Council of Canada and the Natural Sciences and Engineering Research Council of Canada, January 1999. 
atas haruslah ditambah dengan persamaan baru yang diperoleh melalui interpolasi cubic spline.

Untuk masing-masing obligasi ke-i, didefinisikan himpunan $T_{i}=\left\{t_{i 1}, t_{i 2}, \ldots, t_{i n i}\right\}$ diperoleh dari vektor waktu $\mathbf{t}_{i}=\left[\mathrm{t}_{i 1}, \mathrm{t}_{i 2}, \ldots, \mathrm{t}_{i n i}\right]$. Sehingga, gabungan dari $\mathrm{T}_{i}$ yaitu $T=\mathrm{U}_{\mathrm{i}=1}^{\mathrm{K}} \mathrm{T}_{\mathrm{i}}=\left\{\mathrm{t}_{1}, \mathrm{t}_{2, \ldots, \ldots} \mathrm{t}_{\mathrm{N}}\right\}$ adalah himpunan dari semua point-point waktu yang berbeda pada saat pembayaran kupon dan atau nilai pokok yang terjadi pada semua obligasi. Jadi banyaknya anggota himpunan dari $T(|T|)=\mathrm{N}$.

Misalkan notasi nilai terkecil dari anggota pada himpunan $T$ adalah $t_{1}=\min \left\{\mathrm{t}_{11}, \mathrm{t}_{21}, \ldots\right.$, $\left.\mathrm{t}_{\mathrm{K} 1}\right\}$ dan nilai terbesar dari $T$ adalah $\mathrm{t}_{\mathrm{N}}=\mathrm{t}_{\mathrm{Kn} \mathrm{K}^{\prime}}$ maka anggota himpunan $T$ dapat dituliskan dalam urutan dari kecil ke besar sebagai $\left[t_{1}, t_{2}, \ldots, t_{N}\right]$. Oleh karenanya sembarang $t_{i j}$ dari vektor $\mathbf{t}_{i}$ untuk obligasi ke-i, yang didefinisikan di atas merupakan anggota himpunan $T=\left\{t_{1}\right.$, $\left.t_{2, \ldots,} t_{N}\right\}$.

Jika $\mathrm{K}<\mathrm{N}$ sistem persamaan nonlinear di atas tidak bisa dicari solusinya karena jumlah persamaan kurang dari jumlah variabel yang tidak diketahui. Pada kasus seperti ini, perlu diadakan tambahan persamaan dengan cara interpolasi cubic spline beberapa intermediate maturities. Banyaknya poin interpolasi ini dilambangkan sebagai $L=\left\{t_{j} \mid t_{j} \hat{I} T\right.$ dan $\left.t_{j} \ddot{I} K\right\}$. Sehingga anggota dalam himpunan $L$ ada sebanyak $N-K$. Dari data tambahan ini akan diperoleh jumlah persamaan sebanyak $K+L=K+(N-K)=N$ yang berarti sama dengan banyaknya variabel yang tidak diketahui.

\section{Bradley Crane Model}

Bradley-Crane model diperkenalkan oleh Stephen Bradley dan Dwight Crane pada tahun 1987. Model ini mencoba menangkap hubungan non-linear antara yield to maturity dan maturity suatu obligasi ${ }^{11)}$. Persamaan model tersebut adalah sebagai berikut:

$$
\ln (1+\mathrm{YTM})=\mathrm{a}+\mathrm{b}_{1}(\mathrm{M})+\mathrm{b}_{2} \ln (\mathrm{M})+\mathrm{e}
$$

dengan :

ln : logaritma natural

YTM : yield to maturity obligasi

M : masa jatuh tempo (tahun)

e : error

11)Fabozzi, F. J. \& T.D. Fabozzi. The Handbook of Fixed Income Securities Fourth edition. Burr Ridge, New York, 1989. 
Nilai-nilai koefisien dari model di atas diperoleh dengan menggunakan metode jumlah kuadrat terkecil sederhana yaitu dengan meminimisasi jumlah kuadrat error. Jika nilai-nilai parameter model sudah diperoleh, maka yield pada berbagai masa jatuh tempo bisa dihitung. Pemilihan model ini selain mudah dalam perhitungannya juga diangkap cukup akurat, sehingga yield curve yang dihasilkan tidak terlalu fluktuatif.

\section{METODOLOGI}

Data yang digunakan dalam penyusunan yield curve ini adalah hasil transaksi obligasi pemerintah yang bertipe kupon tetap (fixed rate) dan suku bunga rata-rata tertimbang Sertifikat Bank Indonesia 1 bulan dan 3 bulan. Beberapa alasan pemilihan obligasi pemerintah sebagai instrumen dalam penyusunan yield curve diantaranya adalah:

1. Obligasi pemerintah dalam denominasi rupiah merupakan instrumen yang bebas resiko.

2. Masa jatuh tempo obligasi pemerintah bervariasi dan jangka waktunya relatif panjang.

3. Tingkat likuiditas beberapa tipe obligasi pemerintah cukup tinggi.

Sedangkan SBI 1 dan 3 bulan dipilih sebagai reprensentasi tingkat hasil bebas resiko jangka pendek karena beberapa alasan sebagai berikut:

1. Obligasi pemerintah dengan masa jatuh tempo jangka pendek belum tersedia.

2. Penentuan SBI dilakukan dengan sistem lelang (auction system) melalui para market maker sehingga tingkat bunga yang terbentuk mencerminkan kekuatan permintaan dan penawaran.

3. Terdapat transaksi riil dan bukan sekedar kuotasi dari market maker.

4. Kontinuitas data.

Dari hasil transaksi obligasi pemerintah selama satu bulan, kemudian dihitung ratarata tertimbang dari harga obligasi (Weighted Average Price), pembobot yang digunakan adalah market volume transaksi. Sedangkan perhitungan yield untuk maturity 0.0833 dan 0.25 tahun menggunakan rumus bond equivalent yield dari SBI 1 bulan dan 3 bulan.

Metode yang akan digunakan adalah perbanyakan data dengan menggunakan metode generalized bootstrap, kemudian dilakukan pemulusan (smoothing) menggunakan model Bradley-Crane. 


\section{Aplikasi model menggunakan data aktual hasil transaksi obligasi pemerintah pada bulan Febuari 2001}

Sumber data diperoleh dari Bank Indonesia dan Bursa Efek Surabaya, dengan harga obligasi yang digunakan adalah harga rataan tertimbang berdasarkan volume transaksi. Data selangkapnya hasil transaksi obligasi pemerintah pada bulan Febuari bisa dilihat pada Tabel 1.

Tabel 1. Data hasil transaksi obligasi pemerintah bulan Febuari

\begin{tabular}{|c|c|c|c|c|c|c|c|c|}
\hline $\begin{array}{c}\text { Maturity } \\
\text { Date }\end{array}$ & $\begin{array}{c}\text { Last } \\
\text { Coupon }\end{array}$ & $\begin{array}{l}\text { Next } \\
\text { Coupon }\end{array}$ & Bonds & $\begin{array}{c}\text { Number } \\
\text { of } \\
\text { coupons }\end{array}$ & $\begin{array}{l}\text { Annual } \\
\text { Coupons }\end{array}$ & Coupon payment times & Price & Yields \\
\hline $\begin{array}{c}\text { 15-Sep-04 } \\
\text { 15-May-05 }\end{array}$ & $\begin{array}{c}15-S e p-00 \\
15-N o v-00\end{array}$ & $\begin{array}{l}15-M a r-01 \\
15-M a y-01\end{array}$ & $\begin{array}{l}\text { B }_{\mathrm{i}} \\
\text { SBI1mo } \\
\text { SBI3mo } \\
\text { FR0006 } \\
\text { FR0008 }\end{array}$ & $\begin{array}{l}n_{i} \\
1 \\
1 \\
8 \\
9\end{array}$ & $\begin{array}{c}c_{i} \\
0 \\
0 \\
16.5 \\
16.5\end{array}$ & $\begin{array}{c}\mathbf{t}_{i} \\
0.08 \\
0.25 \\
{[0.04,0.54,1.04,1.54,2.04,2.54,3.04,3.54]} \\
{[0.21,0.71,1.21,1.71,2.21,2.71,3.21,3.71,4.21]}\end{array}$ & $\begin{array}{c}p_{i} \\
98.84967 \\
96.24878 \\
97.38800 \\
97.00000\end{array}$ & $\begin{array}{c}r_{n i} \\
0.14962 \\
0.15418\end{array}$ \\
\hline
\end{tabular}

Sumber : Debt Research PT. Danareksa Sekuritas

Karena transaksi yang dilakukan tidak tepat pada saat pembayaran kupon, maka langkah pertama yang dilakukan untuk pembuatan yield curve adalah menghitung accrued interest masing-masing obligasi. Misalnya untuk obligasi FR0006 yang tanggal pembayaran kupon terakhirnya 15 September 2000, maka proporsi dari periode waktu transaksi dengan pembayaran kupon terakhir yaitu 0,1967, sehingga accrued interest untuk FR0006 adalah 7,5625. Sedangkan untuk obligasi FR0008 diperoleh $\mathrm{t}_{0}=0,5833$ dan accrued interest $=4,8125$. Dari hasil tersebut diperoleh bahwa harga kotor (gross price) dari kedua obligasi FR0006 dan FR0008 berturut-turut adalah 104,9505 dan 101,8125.

Tahapan kedua yang harus dilakukan adalah menotasikan data tersebut ke dalam himpunan-himpunan yang telah didefinisikan pada metode generalized bootstrap, yaitu diperoleh $\mathrm{T}=\{0.04,0.08,0.21,0.25,0.54,0.71,1.04,1.21,1.54,1.71,2.04,2.21,2.54,2.71,3.04$, $3.21,3.54,3.71,4.21\}$ dan $K=\{0.08,0.25,3.46,4.29\}$, sehingga $L=\{0.04,0.21,0.54,0.71,1.04$, $1.21,1.54,1.71,2.04,2.21,2.54,2.71,3.04,3.21,3.71\}$. Karena L bukan merupakan himpunan kosong, maka perlu dilakukan perbanyakan data dengan menggunakan cubic spline, sehingga akan diperoleh struktur data yang bisa digunakan untuk perhitungan spot rate pada metode bootstrap atau dengan perkataan lain jumlah persamaan yang dihasilkan akan sama dengan jumlah variabel yang tidak diketahui. Hasil pemulusan cubic spline bisa dilihat di bawah ini: 


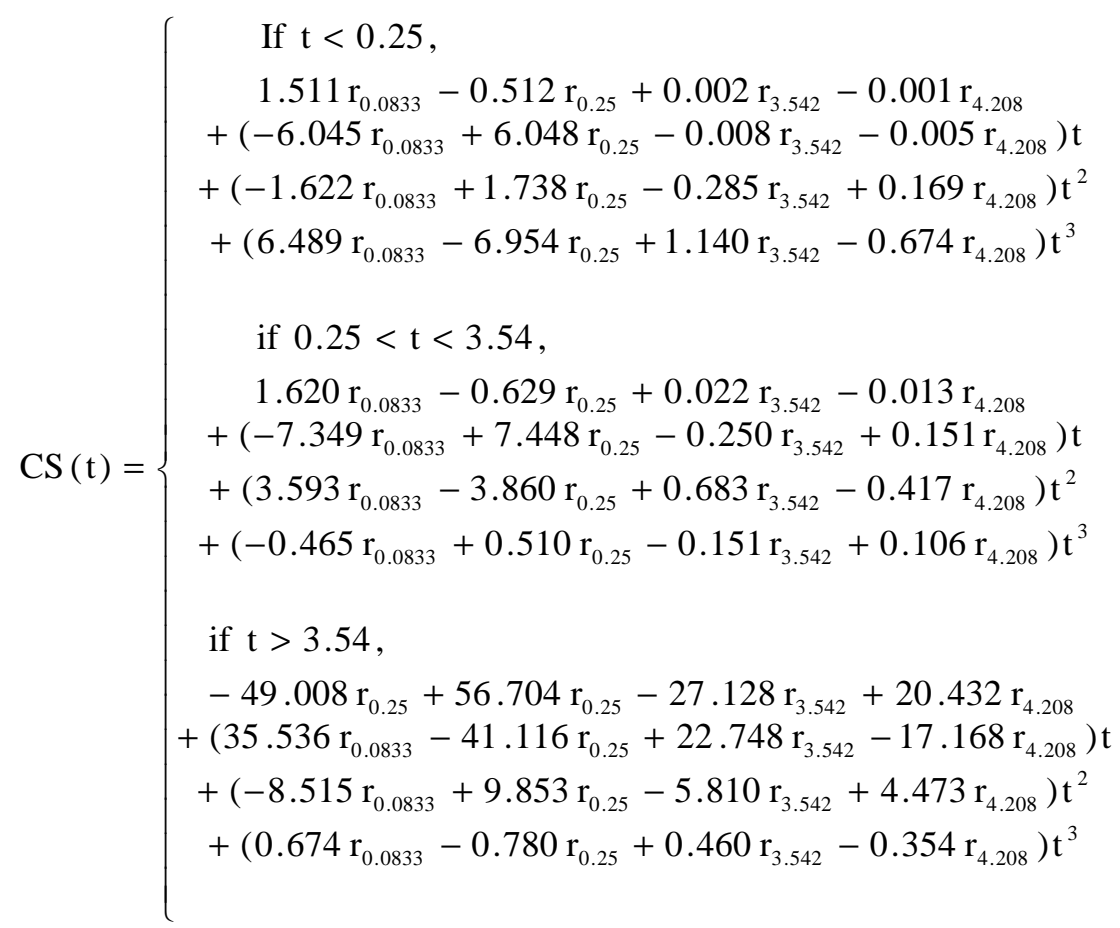

Dari persamaan di atas maka bisa disusun 15 persamaan linear untuk semua titik $t_{j} \in L=\{0.04,0.21,0.54,0.71,1.04,1.21,1.54,1.71,2.04,2.21,2.54,2.71,3.04,3.21,3.71\}$. Interpolasi cubic spline menjamin bahwa setiap titik pada yield curve merupakan kombinasi linear dari titik-titik data obligasi yang diketahui. Persamaan tambahan yang terbentuk adalah sebagai berikut:

$$
\begin{aligned}
& \mathrm{r}_{0.04}=1.256 \mathrm{r}_{0.0833}-0.257 \mathrm{r}_{0.25}+0.001 \mathrm{r}_{3.542}-0.0007 \mathrm{r}_{4.208} \\
& \mathrm{r}_{0.21}=0.240 \mathrm{r}_{0.0833}+0.761 \mathrm{r}_{0.25}-0.002 \mathrm{r}_{3.542}+0.0010 \mathrm{r}_{4.208} \\
& \mathrm{r}_{0.54}=-1.380 \mathrm{r}_{0.0833}+2.354 \mathrm{r}_{0.25}+0.063 \mathrm{r}_{3.542}-0.3699 \mathrm{r}_{4.208} \\
& \mathrm{r}_{0.71}=-1.948 \mathrm{r}_{0.0833}+2.891 \mathrm{r}_{0.25}+0.134 \mathrm{r}_{3.542}-0.0778 \mathrm{r}_{4.208} \\
& \mathrm{r}_{1.04}=-2.662 \mathrm{r}_{0.0833}+3.518 \mathrm{r}_{0.25}+0.332 \mathrm{r}_{3.542}-0.1885 \mathrm{r}_{4.208} \\
& \mathrm{r}_{1.21}=-2.834 \mathrm{r}_{0.0833}+3.635 \mathrm{r}_{0.25}+0.451 \mathrm{r}_{3.542}-0.2524 \mathrm{r}_{4.208} \\
& \mathrm{r}_{1.54}=-2.874 \mathrm{r}_{0.0833}+3.549 \mathrm{r}_{0.25}+0.707 \mathrm{r}_{3.542}-0.3828 \mathrm{r}_{4.208} \\
& \mathrm{r}_{1.71}=-2.767 \mathrm{r}_{0.0833}+3.374 \mathrm{r}_{0.25}+0.836 \mathrm{r}_{3.542}-0.4434 \mathrm{r}_{4.208} \\
& \mathrm{r}_{2.04}=-2.365 \mathrm{r}_{0.0833}+2.830 \mathrm{r}_{0.25}+1.075 \mathrm{r}_{3.542}-0.5406 \mathrm{r}_{4.208} \\
& \mathrm{r}_{2.21}=-2.095 \mathrm{r}_{0.0833}+2.490 \mathrm{r}_{0.25}+1.176 \mathrm{r}_{3.542}-0.5713 \mathrm{r}_{4.208} \\
& \mathrm{r}_{2.54}=-1.483 \mathrm{r}_{0.0833}+1.744 \mathrm{r}_{0.25}+1.321 \mathrm{r}_{3.542}-0.5823 \mathrm{r}_{4.208} \\
& \mathrm{r}_{2.71}=-1.167 \mathrm{r}_{0.0833}+1.367 \mathrm{r}_{0.25}+1.357 \mathrm{r}_{3.542}-0.5567 \mathrm{r}_{4.208} \\
& \mathrm{r}_{3.04}=-0.579 \mathrm{r}_{0.0833}+0.673 \mathrm{r}_{0.25}+1.334 \mathrm{r}_{3.542}-0.4286 \mathrm{r}_{4.208} \\
& \mathrm{r}_{3.21}=-0.332 \mathrm{r}_{0.0833}+0.385 \mathrm{r}_{0.25}+1.267 \mathrm{r}_{3.542}-0.3202 \mathrm{r}_{4.208} \\
& \mathrm{r}_{3.71}=0.066 \mathrm{r}_{0.0833}-0.076 \mathrm{r}_{0.25}+0.795 \mathrm{r}_{3.542}+0.2156 \mathrm{r}_{4.208}
\end{aligned}
$$


Dengan adanya tambahan persamaan tersebut maka akan diperoleh total 19 persamaan, dengan 15 persamaan linear dan 4 persamaan non-linear. Persamaan nonlinear ini diperoleh dari data transaksi obligasi dengan menggunakan rumus dasar perhitungan harga dan atau yield suatu obligasi, yaitu sebagai berikut:

$$
\begin{aligned}
& 9885=\frac{100}{\left(1+\frac{28}{360} \mathrm{r}_{0.0833}\right)} \\
& 9625=\frac{100}{\left(1+\frac{91}{360} r_{025}\right)} \\
& 10495=\frac{8.25}{\left(1+\frac{r_{0.041}}{2}\right)^{0.083}}+\frac{8.25}{\left(1+\frac{r_{0.542}}{2}\right)^{1.083}}+\frac{8.25}{\left(1+\frac{r_{1.042}}{2}\right)^{20.83}}+\frac{8.25}{\left(1+\frac{r_{1.542}}{2}\right)^{3.083}}+\frac{8.25}{\left(1+\frac{r_{2042}}{2}\right)^{4.083}}+\frac{8.25}{\left(1+\frac{r_{2542}}{2}\right)^{5.083}}+\frac{8.25}{\left(1+\frac{r_{3.042}}{2}\right)^{6.083}}+\frac{10825}{\left(1+\frac{r_{3.542}}{2}\right)^{7.083}} \\
& 10181=\frac{8.25}{\left(1+\frac{r_{0.201}}{2}\right)^{0.417}}+\frac{8.25}{\left(1+\frac{r_{1.708}}{2}\right)^{1.417}}+\frac{8.25}{\left(1+\frac{r_{1.208}}{2}\right)^{2417}}+\frac{8.25}{\left(1+\frac{r_{1.708}}{2}\right)^{3.417}}+\frac{8.25}{\left(1+\frac{r_{2208}}{2}\right)^{4.417}}+\frac{8.25}{\left(1+\frac{r_{2708}}{2}\right)^{5.417}}+\frac{8.25}{\left(1+\frac{r_{3208}}{2}\right)^{6.417}}+\frac{8.25}{\left(1+\frac{r_{3.708}}{2}\right)^{7.417}}+\frac{10825}{\left(1+\frac{r_{4208}}{2}\right)^{8.417}}
\end{aligned}
$$

Karena jumlah persamaan sama dengan jumlah variabel yang tidak diketahui, maka pencarian solusi sistem persamaan tersebut dapat drselesaikan dengan mudah. Tahapan penyelesaiannya adalah sebagai berikut:

1. Substitusi persamaan yang diperoleh dari interpolasi cubic spline ke persamaan nonlinear.

2. Hasil langkah 1 menjadikan sistem persamaannya lebih sederhana, cari penyelesaian hanya untuk 4 variabel $\left(\mathrm{r}_{0.0833}, \mathrm{r}_{0.25}, \mathrm{r}_{3.461}, \mathrm{r}_{4.292}\right)$.

3. Jika variabel pada tahap kedua diperoleh, maka disubstitusikan ke persamaan pada interpolasi cubic spline, sehingga diperoleh semua nilai variabelnya.

Hasil penyelesaian sistem persamaan di atas dapat dilihat pada Tabel 2 di bawah ini:

Tabel 2. Hasil perhitungan generalized bootstrap

Tenor (tahun)

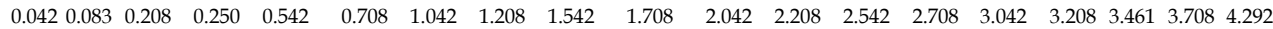

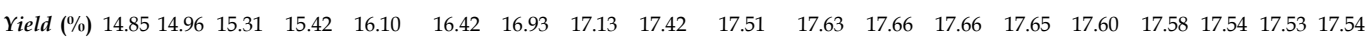

Dari hasil perhitungan generalized bootstrap memungkinkan untuk dilakukan pemulusan menggunakan model Bradley Crane. Dengan menggunakan metode OLS (Ordinary Least Square) diperoleh model sebagai berikut: 
$\ln (1+\mathrm{YTM})=0.1567-0.0008$ maturity $+0.007 \ln$ (maturity)

Hasil selengkapnya analisis Bradley Crane model bisa dilihat pada Tabel 3.

Tabel 3. ANOVA dan t-test hasil Ordinary Least Square Bradley Crane Model

SUMMARY OUTPUT

\begin{tabular}{lr}
\hline \multicolumn{2}{c}{ Regression Statistics } \\
\hline Multiple R & 0.97156782 \\
R Square & 0.943944029 \\
Adjusted R Square & 0.936937033 \\
Standard Error & 0.002197887 \\
Observations & 19 \\
\hline
\end{tabular}

ANOVA

\begin{tabular}{|c|c|c|c|c|c|}
\hline & $d f$ & SS & $M S$ & $F$ & Significance $F$ \\
\hline Regression & 2 & 0.001301532 & 0.000651 & 134.7145 & $9.74934 \mathrm{E}-11$ \\
\hline Residual & 16 & 7.72913E-05 & 4.83E-06 & & \\
\hline Total & 18 & 0.001378824 & & & \\
\hline
\end{tabular}

\begin{tabular}{lcccccccc}
\hline & Coefficients & Standard Error & $t$ Stat & $P$-value & Lower 95\% & Upper 95\% & Lower 95.0\% & Upper 95.0\% \\
\hline Intercept & 0.156712259 & 0.001522885 & 102.9048 & $5.274 \mathrm{E}-24$ & 0.153483887 & 0.15994063 & 0.153483887 & 0.159940631
\end{tabular}

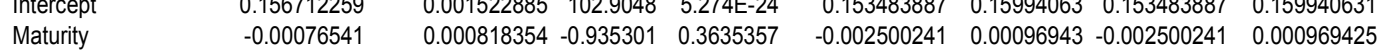

\begin{tabular}{lllllllll} 
In (Maturity) & 0.006986094 & 0.000815813 & 8.563351 & $2.269 \mathrm{E}-07$ & 0.005256648 & 0.00871554 & 0.005256648 & 0.00871554 \\
\hline
\end{tabular}

Jika dibuat plot antara yield dan maturity dari hasil smoothing tersebut, maka diperoleh yield curve untuk bulan Febuari 2001 seperti terlihat pada Gambar 1.

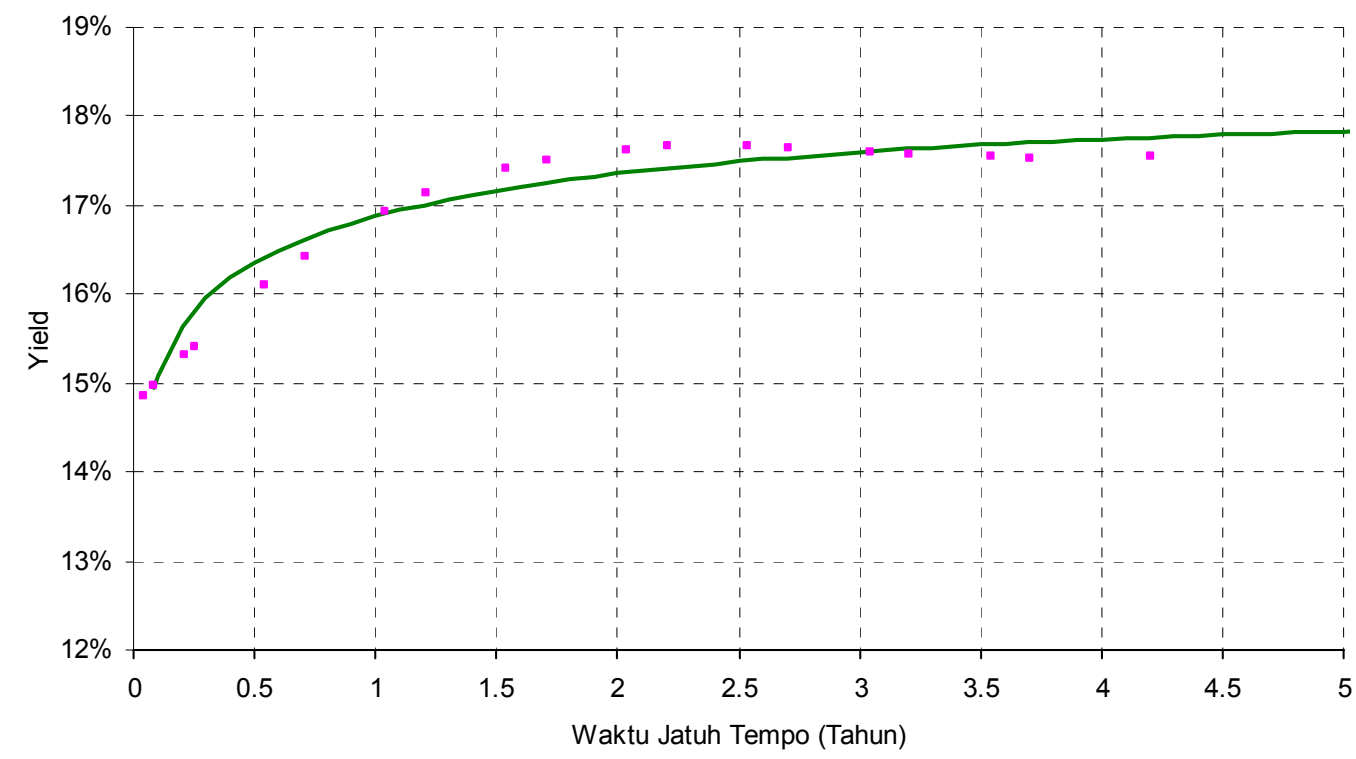

Gambar 1. Indonesian Yield curve bulan Februari 2001 
Aplikasi untuk beberapa bulan berikutnya menghasilkan yield curve yang cukup stabil sebagaimana terlihat dari tampilan pada Gambar 2.
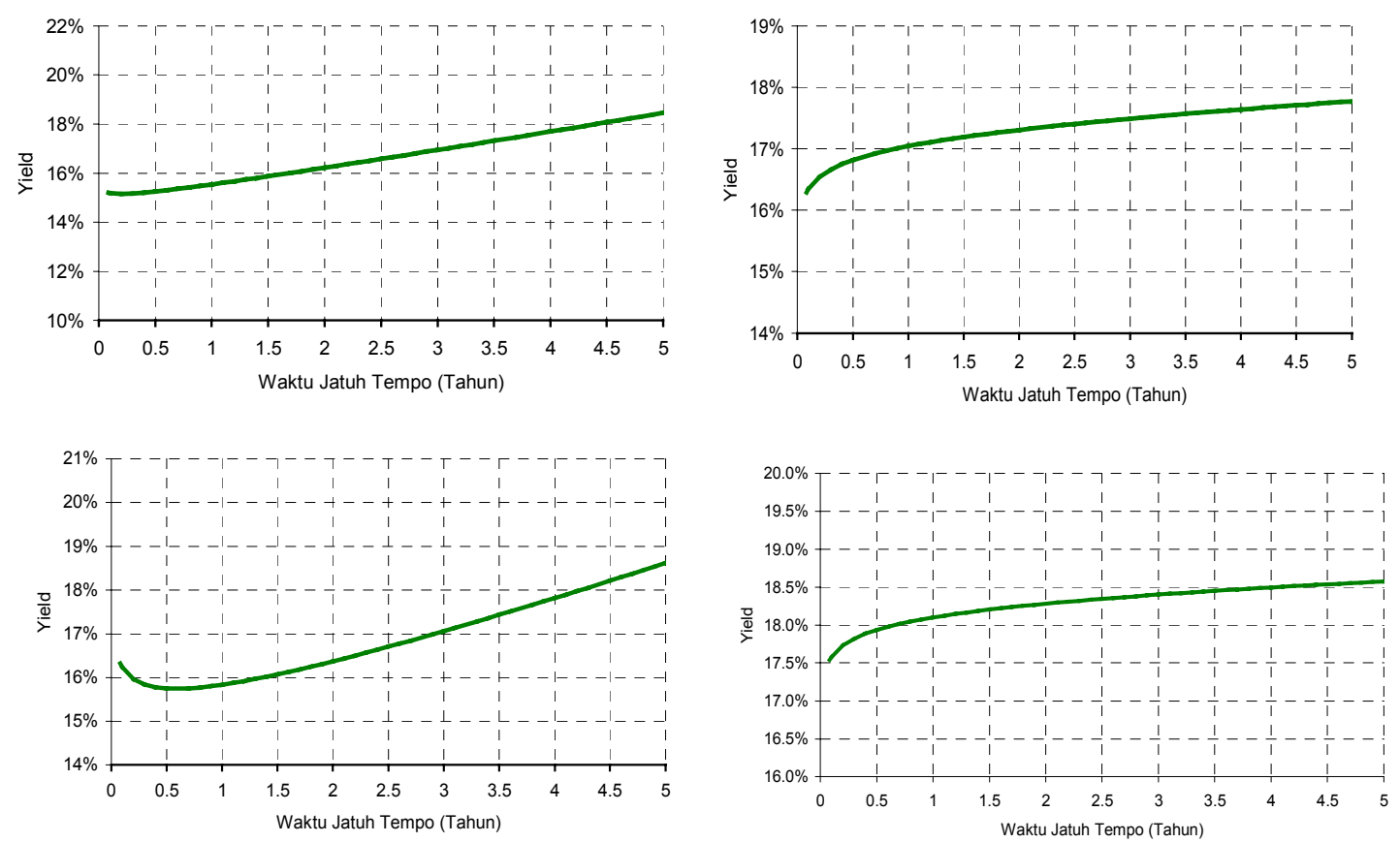

Gambar 2. Indonesian Yield Curve Maret-Juni 2001

\section{KESIMPULAN}

Pasar instrumen berpendapatan tetap (fixed income) di Indonesia sangat membutuhkan kehadiran yield curve sebagai benchmark dalam penentuan harga. Keberadaan pasar sekunder obligasi pemerintah memberi peluang bagi terciptanya benchmark tersebut, meskipun masih ada beberapa permasalahan mendasar seperti likuiditas dan terbatasnya data pada setiap titik maturity.

Metoda generalized bootstrap method terbukti mampu memecahkan masalah illiquidity dan missing data point dalam penyusunan yield curve. Masalah missing data point diatasi dengan melakukan spline dengan ordo polinomial pangkat tiga (cubic spline). Pemilihan cubic spline ini menjamin bahwa fungsi yang dihasilkan akan kontinu pada setiap titik dan juga dapat diturunkan sebanyak dua kali. Dengan adanya perbanyakan data tersebut, kemudian dilakukan pemulusan menggunakan model Bradley Crane. Pemilihan model ini selain dikarenakan mudah dalam perhitungannya juga cukup akurat. Dengan adanya proses pemulusan yield curve yang dihasilkan tidak terlalu fluktuatif. Studi lebih lanjut 
mengenai perbandingan penyusunan yield curve di negara-negara lain yang mungkin cocok diaplikasikan di Indonesia akan memberikan kontribusi bagi penyempurnaan model ini. Pencarian model yang terbaik tercermin dari semakin kecilnya MAPE dan kestabilan yield curve yang terbentuk setiap bulannya.

\section{DAFTAR PUSTAKA}

Atkinson. 1994. Elemenary Numerical Analysis second edition. John Willey \& Son, Singapore.

Bradley, S.P. \& D. B. Crane. 1973. Management of Commercial Bank Government Security Portfolio: An Optimization Approach under Uncertainty. Journal of Bank Research. Spring pp. 18-30.

Deaves, R. \& M. Parlar. 1999. A generalized Bootstrap Method to Determine the Yield curve. Research supported by the Social Sciences and humanities Research Council of Canada and the Natural Sciences and Engineering Research Council of Canada.

Echols, M. E. \& J. W. Elliot. 1976. A Quantitative Yield curve Model for Estimating the Term Structure of Interest Rate. Journal of Financial and Quantitative Analysis. pp. 87-114

Fabozzi, F. J. \& T.D. Fabozzi. 1989. Bond Markets, Analysis and Strategies. Prentice Hall, Englewood Cliff, New Jersey.

Fabozzi, F. J. \& T.D. Fabozzi. 1989. The Handbook of Fixed Income Securities Fourth edition. Burr Ridge, New York.

McCulloch, J. H. 1971. Measuring Term Structure Interest Rate. Journal of Business, 44:19-31

Nelson, C. R. \& A.F. Siegal. 1987. Parsimonious Modeling of yield curve. Journal of Business. pp. 473-489

Ryan, Ronald J. (ed), 1997. Yield Curve Dynamics. Fitzroy Dearbon Publisher, Chicago and London. 
Svensson, L.E.O. 1994. Estimating and Interpreting Forward Interest Rate: Sweden 1992-1994. Technical Report Discussion Paper Number 1051, Centre for Economic Policy Research, October 1994

Vasicek, O.A. \& H.G. Fong. 1982. Term Structure Modeling using Exponential Spline. Journal of Finance, 329:348

\section{RIWAYAT HIDUP}

PAULUS NURWADONO, dilahirkan di Yogyakarta 24 Maret 1968. Lulus dari jurusan Ilmu Ekonomi dan Studi Pembangunan FE-UGM tahun 1991, dan kemudian menjadi staf peneliti di Pusat Antar Universitas (PAU) Studi Ekonomi UGM. Dengan beasiswa Ford Foundation, penulis memperoleh gelar Master of Science in Economics dari Department of Economics, National University of Singapore pada tahun 1996. Saat ini penulis adalah Director, Head of Fixed Income Research, PT. Danareksa Sekuritas.

HANDY YUNIANTO. Dilahirkan di Jepara 2 Juni 1977. Lulus dari jurusan Statistika IPB pada tahun 2000. Program penunjang yang digeluti selama ini adalah ekonomi dan komputasi. Semasa studi penulis aktif di Himpunan Profesi Mahasiswa Statistika Gamma Sigma Beta pada Departemen Informasi dan Komunikasi dan menjadi Asisten Dosen mata kuliah Statistika Dasar (STK 551) pada Program Pasca Sarjana IPB. Saat ini penulis adalah Assitant Manager di divisi Fixed Income Research PT Danareksa Sekuritas. 